\title{
Regionalt våbenkapløb og en eventuel arabisk a-bombe
}

\section{Riad Kahwaji}

Hvis Iran anskaffer sig atomvåben og dermed opnår atomar magtbalance med Israel kan det skabe en følelse af svaghed og sårbarhed hos arabiske ledere, som så vil søge at genoprette magtbalancen over for ikke-arabiske stater i regionen

Mange embedsmænd og andre iagttagere i de arabiske Golfstater tror, at det kun er et spørgsmål om tid, før Iran bliver i stand til at producere sine egne atomvåben. Kun få tror, at USA, Israel og det internationale samfund kan gøre noget som helst politisk eller militært - for at forhindre denne forventede ny virkelighed.

Og endnu færre tror, at sanktioner vil afskrække Teheran fra at blive den næste atommagt.

Men i lighed med resten af verden synes de ikke at have en klar forestilling om, hvordan man skal omgås et Iran med atomvåben. Ikke desto mindre er der talrige muligheder på forskellige niveauer, inklusive defensive militære forholdsregler og en vestlig atomparaply for at afskrække fremtidige iranske trusler. På lang sigt kunne man også tilstræbe en arabisk atombombe.

Muligheden for at Iran besidder atomvåben, er allerede begyndt at påvirke de arabiske Golfstater. De har næsten alle bekendtgjort, at de har til hensigt at anskaffe kernekraft til fredelige formål. Fire af dem, især de Forenede Arabiske Emirater (UAE) og Saudi-Arabien, har været på storindkøb, hvor de har underskrevet aftaler, der vil styrke deres forsvar i luften og til søs.

Saudierne har købt 72 kampfly af typen Typhoon Eurofighter og opgraderet deres AWACS varslings- og overvågningsfly og deres Patriot anti-ballistiske missilbatterier.

UAE har for sit vedkommende bestilt THAAD luftforsvars-missilsyste- 
met mod højtgående trusler sammen med Patriot PAC-3 missiler og andre supplerende systemer med henblik på at etablere et fuldt integreret flerstrenget ballistisk missilforsvarsskjold. UAE har desuden påbegyndt forhandlinger med Frankrig om køb af 60 kampfly af typen Rafael, og modtager snart den første af seks multipurpose missilkorvetter af klassen Baynunah plus diverse systemer til at bekæmpe undervandstrusler og forbedre informations-, overvågnings- og rekognosceringskapabiliteter til søs.

\section{Stigende spænding}

På den måde har stigende spænding på grund af Irans kontroversielle atomprogram udløst et våbenkapløb i de arabiske Golfstater og øget interessen for at anskaffe en nuklear kapabilitet. Samtidig har Golfstaterne holdt kommunikationskanalerne til Iran vidt åbne i et forsøg på at mindske spændingen mellem de to parter, især spændingen mellem sunnitter og shiitter som følge af den interne magtkamp i Irak og Libanon og det nylige strid mellem Cairo og Hizbollah angående sidstnævntes rolle i våbensmugleri gennem Egypten til Gaza.

Den i forvejen stærke etno-sekteriske spænding mellem Iran og dets arabiske naboer omkring Golfen vil sandsynligvis stige, hvis Teheran begynder at fremstille kernevåben. Den arabiske side frygter såvel iransk overherredømme som en aftale mellem Washington og Teheran på bekostning af arabiske interesser.

Mange arabiske embedsmænd og analytikere tror, at Washingtons manglende evne til at kontrollere det iranske atomprogram vil tilskynde USA til at gå efter en politisk aftale med Iran på sidstnævntes vilkår, bedre kendt som 'den store aftale'.

Teheran har indtil videre nægtet at diskutere atomspørgsmålet adskilt fra andre spørgsmål så som Irak, Libanon, fredsprocessen og Irans rolle som regional magt. Iranske ledere har længe insisteret på én samlet aftale med Washington, der omfatter alle udeståender mellem de to.

\section{Nye strategier}

Øget spænding og formindsket tillid til deres vigtigste strategiske allierede, USA, kan drive de arabiske Golfstater i retning af større selvstændighed med hensyn til at søge at forsvare sig selv ved hjælp af effektiv afskrækkelse over for et Iran med atomvåben.

Eller de kan blive opmuntret til at søge nye strategiske allierede som hjælper USA eller om nødvendigt erstatter det. Åbningen af en ny fransk flådebase i Abu Dhabi den 26. maj i år var et eksempel på denne tendens. Det var den første ikkeamerikanske base i Golfområdet, og yderligere ikke-amerikanske baser kan blive åbnet i området i fremtiden. 
Indvirkningen på den arabiske gade, inklusive Golfen, af Irans stærke retorik om støtte til modstanden og kampen mod Israel har været betydelig. Hvis Teheran anskaffede sig atomvåben, ville araberne føle sig forlegne over, at det ikke var lykkedes dem at opnå atomar magtbalance med Israel, når det nu var lykkedes iranerne.

Dette ville skabe en følelse af svaghed og sårbarhed hos mange arabiske ledere, som sandsynligvis ville søge at genoprette magtbalancen over for ikke-arabiske stater i regionen.

Manglen på fremskridt i fredsprocessen ville også anspore mange arabere til at opfordre deres ledere til at efterligne Irans afvisende og konfrontatoriske fremgangsmåde. Den synes i høj grad at have været en succes, mens det ikke er lykkedes araberne med deres fredelige og mådeholdne fremgangsmåde at opnå, hvad de anser som en 'fredelig og retfærdig løsning' på den arabiskisraelske kamp i almindelighed og den palæstinensiske sag i særdeleshed.

Hvis USA og det internationale samfund kan lære at leve med et Iran med atomvåben, vil den almindelige arabiske antagelse være, at så skulle verden også kunne leve med en arabisk atombombe.

Det vil sansynligvis ikke ske i løbet af et eller to år, men regional geopolitik og simpel logik ville føre til denne slutning. Det er derfor sandsynligt, at fremtidige militære konflikter, især hvis de byggede på etnosekteriske forskelle i Mellemøsten, ville udvikle sig til ødelæggende atomkrige.

Riad Kahwaji er grundlagger af og direktør for Institute for Near East $\mathcal{E}^{\circ}$ Gulf Military Analysis (INEGMA). Artiklen er offentliggjort $i$ bitterlemonsinternational.org, edition 10 volume 7 , den 28. maj.

(C) bitterlemons-international.org

Oversat fra engelsk af Brita $V$. Andersen. 